\title{
Islamic welfare system dealing with the poor in rural area
}

\author{
Zakiyah
}

Institute for Research and Development, Ministry of Religious Affairs, Central Java, Indonesia

Email:zaki_smart@yahoo.com

\begin{abstract}
This paper try to review the practice of Islamic welfare system (such as zaka, waqf, shadaqa, infaq, hibah and qurban) dealing with poor people in rural area. Then, this study looks at four main issues, namely how the structure of the commitee, the management of such system, fund rising strategy, and people accessibility to this welfare system. In order to deal with this, it is used some frameworks namely; firstly, the welfare strategy as proposed by Spicker (1995) including economic production, redistribution, and solidarity. Secondly, the concept of welfare offered by Azmi (1991), Midgley (1997), and Zastrow (2004). This research took place in North and South Wonorejo, a village located in Magelang district, Central Java. Finding of this research shows that this scheme has operated conventionaly and has not contributed much on enhancing people welfare. There is no formal institution that organizes all element of such scheme. As the social welfare institution, this system ideally offers program, benefits and services that help people meets those social, economic, educational and health needs. However, there is no specific program for the poor people offered by the committee of the Islamic welfare scheme.
\end{abstract}


Studi ini berusaha mengkaji praktik system kesejahteraan dalam Islam (seperti zakat, wakaf, shadaqah, infak, hibah dan qurban) dalam hubungannya dengan masyarakat miskin di wilayah pedesaan. Kajian melihat empat persoalan utama, yakni bagaimana struktur panitia, pengelolaan sistem kesejahteraan, strategi pengumpulan dana, dan akses masyarakat terhadap sistem tersebut. Untuk menjawab persoalan ini, kajian mempergunakan kerangka kerja antara lain strategi kesejahteraan sebagaimana diusulkan Spicker (1995) termasuk produksi, redsitribusi, dan solidaritas ekonomi, dan konsep kesejahteraan sebagaimana dikemukakan Azmi (1991), Midgley (1997), dan Zastrow (2004). Kajian ini dilakukan di Desa Wonorejo Utara dan Selatan, Magelang, Jawa Tengah. Kajian ini menemukan antara lain: skema kesejahteraan masih dilakukan secara konvensional dan tidak banyak berkontribusi terhadap kesejahteraan masyarakat. Tidak ada lembaga resmi yang mengorganisir semua unsur dalam skema tersebut. Sebagai lembaga kesejahteraan sosial, sistem ini idealnya menawarkan program, manfaat dan layanan yang menolong masyarakat dalam memenuhi kebutuhan-kebutuhan ekonomi, sosial, pendidikan dan kesehatan. Namun demikian, tidak ada program khusus bagi masyarakat miskin yang ditawarkan oleh pengelola skema kesejahteraan Islam.

Keywords: Islam; Welfare system; Poor; Empowerment

\section{Introduction}

Indonesian people mostly live in rural areas and most of them are poor. Data from Central Bureau of Statistic and ministry of social affairs shows that in 2002 there were 35 million poor people or equally the same as 17.5 percent of total population. This number will be larger if the rate of poverty is counted using a standard issued by World Bank which states each person must have income at least 2 US dollar a day. This number is predicted increase yearly because of the economic uncertainty and some of the natural disaster like earthquake, flood and others.

Based on the economic condition, poor people have the rights to get assistance from formal or informal welfare systems. The welfare 
institution ideally assists them in order to enhance their wellbeing. In relation to this notion, in Islam there is actually a welfare scheme including several forms of wealth redistribution such as zaka (an obligatory alms giving), shadaqa (voluntary giving primarily for the poor), infaq (Voluntarily giving in the form of financial giving), and hibah (voluntary giving/charity), waqf (philanthropic endowment) as well as qurban (immolation) ${ }^{1}$ This system can be an important way to deal with poor people due to the facts that the majority of Indonesian are Muslim, and such people are Muslim too. ${ }^{2}$

This paper examines the Islamic welfare system responding to the above problem faced by poor people. This study argues that ideally Islamic welfare system provides assistance to the needy; so that these people can achieve their basic need. Therefore, as poor people, they can be categorized as one of the zaka receiver together with others. The Quran $(2 ; 177)$ mentions eight categories of zaka beneficiaries namely, the poor and the destitute, the wayfarer, the bankrupt, the needy, converts, captives, the collectors of zaka, and in services of God. ${ }^{3}$ Furthermore, the purpose of the Islamic welfare system is to

\footnotetext{
${ }^{1}$ Umer Chapra, "The Islamic Welfare State and its Role in the Economy", In K. Ahmad (ed.), Studies in Islamic Economic, Leicester, U.K: The Islamic Foundation, 1980, 143-169. Also look at: Faridi, "Zaka and Fiscal Policy", In K. Ahmad (ed.), Studies in Islamic Economic, Leicester, U.K: The Islamic Foundation, 1980, 119-129; S. Sabiq, Fikih Sunah 3, Bandung: PT Alma'arif, 1978; M.D. Ali, Sistem Ekonomi Islam: Zakat dan Wakaf, Yogyakarta: UII Press, 1988; Inoed, et. al. Anatomi Fiqh Zakat, Yogyakarta: Pustaka Pelajar, 2005; H.A. Shiddieqy, Pedoman Zakat, Semarang: Pustaka Rizki Putra, 2005.

${ }^{2}$ Central Statistic Bureau (BPS), Kabupaten Magelang dalam Angka Tahun 2004, Magelang: Bps Kabupaten Magelang: 2004. Also looked at BPS (2001, 2003, 2004, 2005). Potensi Daerah Jawa Tengah (Potency of Central Java Province), retrieved December 2005, from http:// www.bps.gov.id; BPS, Kecamatan Bandongan dalam Angka Tahun 2003, Magelang: BPS Kabupaten Magelang, 2003.

${ }^{3}$ S. Sabiq, Fikih Sunah 3, Bandung: PT Alma'arif, 1978; M.D. Ali, Sistem Ekonomi Islam: Zakat dan Wakaf, Yogyakarta: UII Press, 1988.
} 
bring justice in the society by at least ensuring minimum livelihood of every individual in the community. ${ }^{4}$

However, why in the reality there are still many people not able to reach the minimum standard of basic need. Therefore this paper focuses on how the Islamic welfare system confronts people's problems, and then poor people's accessibility as the beneficiaries to such schemes is explored. These two elements are crucial part to analyze what really going on the society. Moreover, this paper is based on research taken place in North Wonorejo and South Wonorejo, Banyuwangi, Magelang District Central Java. This village is a rural area with high number of people live in need.

\section{Conceptual framework}

This paper uses some concepts that need to be defined. Firstly, the notion of Islamic welfare system is defined as a strategy for enhancing human wellbeing. In analyzing these matters, researcher looks at the welfare strategy as proposed by Spicker (1995) including economic production, redistribution, and solidarity. ${ }^{5}$

One of the main purposes of social welfare provision is to improve economic production. So that, by looking back in the economic level, it allows us to understand their income and how these people spend it to fulfill their basic needs. In this case, researcher uses the concept of welfare as offered by Azmi (1991), Midgley (1997), and Zastrow (2004), ${ }^{6}$ but this idea is instead emphasized on wellbeing in which the human

${ }^{4}$ Faridi, "Zaka and Fiscal Policy", in K. Ahmad (ed.) Studies in Islamic Economic, Leicester, U.K: The Islamic Foundation, 1980, 119-129.

${ }^{5}$ P. Spicker, Social Policy Themes and Approaches, England: Prentice Hall, 1995.

${ }^{6}$ S.H. Azmi, "Traditional Islamic Social Welfare: Its Meaning, History and Contemporary Relevance", The Islamic Quarterly, XXXV (1991); also looked at J. Midgley, Social Welfare in Global Context, London: Sage Publication, 1997; Zastrow, The Practice of Social Work, USA: Brooks/Cole Publishing Company, 1999. 
achieves their basic needs, and then implementation of the Islamic spiritual value in the daily life. Besides, the assets of the people are also looked as one of the indicators of wellbeing, ${ }^{7}$ and then, how the Islamic welfare system respond to the people' welfare.

To understand the concept of welfare in Islam, it is important to learn the nature of man as Azmi (1991) mentions in his article. Man is, in this case, described as not only a material but also spiritual being with reference to divine revelation. ${ }^{8}$. Thus, individual welfare consists of two things namely: (1) a fuller implementation of Islamic spiritual value in the daily life, (2) a sufficient achievement of all basic material needs of life. ${ }^{9}$

To promote the welfare of the people, Spicker $(1995)^{10}$ suggests three strategies namely (1) economic production, (2) redistribution, (3) social security and solidarity. Economic production means supporting people to enhance their material goods or their economic condition. There are two main ways to reach this economic growth; (1) creating condusif conditions for growth like free enterprise, eliminating obstacle and restrictions (including taxation and government intervention); (2) state intervention in many aspect of economic life such as creating planning in industrial development, supporting public resources and ensuring people involved in economic activity (as employment).

Redistribution means taking resources from some people and giving to others. There are two kinds of redistribution; (1) vertical redistribu-

\footnotetext{
${ }^{7}$ M. Sherraden, Assets and the Poor: A New American Welfare Policy, New York: M.E.Sharpe Inc., 1991.

${ }^{8}$ S.H. Azmi, "Traditional Islamic Social Welfare: its Meaning, History and Contemporary Relevance", The Islamic Quarterly, XXXV (1991).

${ }^{9}$ Umer Chapra, "The Islamic Welfare State and its Role in the Economy", in K. Ahmad, (ed.) Studies in Islamic Economics, Leicester, U.K: The Islamic Foundation, 1980, 143.

${ }_{10}$ P. Spicker, Social Policy Themes and Approaches, England: Prentice Hall, 1995, 60.
} 
tion including progressive (from rich to poor) and regressive (from poor to rich). To increase welfare, in this part, involves transferring money from the have to the have not; (2) Horizontal redistribution is from one kind of group to another, for instance for men to women, tenants to owners-occupier, family without children to family with children. This type of redistribution is much more complex than the previous one because it includes not only transferring money but also a way of changing patterns of behaviour in society or encouraging behavior.

Social security and solidarity are components of welfare provision by providing financial, health care and income assistance. Social security is intended to assist people when the time of need, for example health care service protects people who are sick. This social security is developed from mutual aid societies or trade union in which members agree to take risk and responsibility for support. This principle is in conjunction with the idea of solidarity which refers to mutual aid and collective social action. ${ }^{11}$

Furthermore, there are at least three methods for supporting social welfare: firstly, social philanthropy that relies on individual donation and some attempts done by nonprofit organization to solve many problems in the society. Secondly social work based on the professional personnel to advance the aims of welfare through collaborative work with individual, group and community. Lastly, it is social administration or government intervention, like providing social services which is called social policy approach. ${ }^{12}$

In relation to the Spikers' view, zaka can be classified as a kind of redistribution whis is the progressive one that distributing wealth from the have to the have not. Horizontal redistribution is from one kind of

${ }^{11}$ P. Spicker, Social Policy Themes and Approaches, England: Prentice Hall, 1995, 60.

12 J. Midgley, Social Welfare in Global Context, London: Sage Publication, 1997, 16. 
group to another for instance from men to women, tenants to owneroccupiers. In this part, researcher looks at Islamic welfare system as a kind of vertical redistribution to bring social justice and eliminate inequality between rich and poor people.

The notion of solidarity can be described as mutual aid or collective social action. In the Islamic term, there are, shadaqa, infaq, and hibah as earlier explained that are aimed for improving human welfare. These are seen as a kind of solidarity too. Indeed, how people assist another one is not only considered as aid but also as the basis of social provision. Furthermore, to ensure that this institution is easily accessed, researcher examines at the accessibility of poor people as one of the qualified group of receivers toward these institutions. In this case, the systems have to be accessible for the reason that the impact of inaccessibility is to deny the opportunity to gain this welfare. ${ }^{13}$

\section{Research method}

This is a descriptive research using qualitative approach in order to gather an in-depth understands of the poor people and Islamic welfare system as social phenomena. The descriptive study describes, records and reports phenomena that can provide crucial information for establishing and developing social program. This approach may also be called survey research that focuses on describing the characteristic of the group. ${ }^{14}$ This research will generate questions to be investigated by more extensive studies using either the exploratory or the explanatory study. Subject of this study is poor people who live in North Wonorejo and South Wonorejo Banyuwangi Magelang district Central Java. Reli-

${ }_{13}$ P. Spicker, Social Policy Themes and Approaches, England: Prentice Hall, 1995, 60, 175.

${ }^{14}$ C. Marlow, Research Methods for Generalist Social Work, Toronto: Brooks/Cole, 2001, 32-35. 
gious leader and a chief of RW (Rukun Warga/administrative unit at the next-to lowest level in the city) as well as the board of the Islamic welfare system also are subjects for this study. These people are selected using purposive sampling method means selecting people who can provide information about given problem (People that are information rich or those with expertise on the research topic). ${ }^{15}$

This research used two main methods to gather the data namely (a) document research and (b) interview. The document research is applied in searching publication or written data issued by the government on the community in the area under study. Meanwhile, interview was conducted with such selected people.

\section{The elements of islamic welfare system}

Islam is undoubtedly concern with the welfare of the people: it can be seen from the mission of holy prophet as defined in the Qur'an which is to be a merciful blessing for all mankind (Rahmat li al-'alamin) (2:107). Some further explanations about implementation of these notions are clearly stated in several verses of Quran including: (1) promoting a good life and welfare as mention in chapter two verse seventy seven: "whoever male or female, does good and is a believer, We shall certainly make him life a good life and give him his reward for the best of what he did" (2:77), (2) alleviating hunger and fear (106:4), and (3) generating prosperity (7:58). To achieved the above ideals, Islam offers many paths, one of them is the Islamic welfare system consisting zaka, shadaqa, infaq, hibah, waqf and qurban (immolation).

${ }^{15}$ E. Babbie, The Practice of Social Research (eight edition), USA: Wadsworth Publishing Company, 1998, 195. Also looked at C. Marlow, Research Methods for Generalist Social Work, Toronto: Brooks/Cole, 2001, 144; B.L. Yegidis \& R.W. Weinbach, Research Method for Social Work (2nd Edition), Needham, MA: Allyn and Bacon, 1996, 154-155. 
The first element is zaka, this term derives from the word zaka which implies "to thrive", "to be nourishing", or "to be pure". Zaka is a giving up of a portion of wealth from the have to the have-not as a way to purify or legalize it. ${ }^{16}$ This act is called zaka because it purifies the wealth and the soul of the payers. ${ }^{17}$ Zaka is an obligatory almsgiving for every Muslim to share with Muslim in need like the poor, destitute and wayfarer. Zaka places as the third pillar of Islam together with the declaration of faith, prayer, fasting and the pilgrimage to Mecca. Besides, this is not only as a form of worship of God but also as a service to the community as mentioned in this verse:

"It is not righteousness that ye turn your faces towards East or West: but it is righteousness, to believe in Allah and the Last Day, and the Angels and the Book, and the Messengers: to spend of your substance, or of love for Him, for your kin, for orphans, for the needy, for the wayfarer, for those who ask, and for the ransom of slaves: to be steadfast in prayer, and give Zakah, to fulfil the contracts which ye have made: and to be firm and patient, in pain (or suffering) and adversity, and throughout all periods of panic, such are the people of truth, the God-fearing." (Quran, Hūd 11:177)

Keeping in mind that this verse explains social welfare as a basic Islamic value for human being, its meaning emphasizes the integration of the five pillars of Islam together with providing welfare for community. In this verse, the Qur'an reminds the believer that the pronouncement of faith in Allah, Qur'an (a holy book) and last day is not enough on condition that they do not care for relatives, orphans, the needy and travelers, people who asked for helping as well. ${ }^{18}$ Therefore, Islam

${ }^{16}$ M.W. Khan, The Concept of Charity in Islam, 2005. Retrieved January 2006, from http:/ /www.alrisala.org/intro_page_link/article_categories.html

${ }^{17}$ M. Kahf, "The Principle of Socioeconomic Justice in the Contemporary Fiqh of Zaka", Iqtisad Journal of Islamic Economics, Volume 1, Number 1 (1999): 24-44.

${ }^{18}$ A. Ahmad, "Social Welfare: A Basic Islamic Value", Journal of Hamdard Islamicus, Volume XX, Number 3 (1997), retrieved 2005, from http://www.muslim-canada.org/articles.html 
has established this institution to make concern for the poor a permanent and compulsory duty, this form of welfare system is supposed to bridge the gap between rich and poor members of the (Muslim) community.

There are two types of zaka namely zaka fitra and zaka māl. The first category is disbursed by each Moslem after fasting month of ramadhan in order to purify their soul and enable them to celebrate idul fitri (a day of celebration at the end of fasting month). This type of zaka can be given in the form of food or its monetary equivalent. The second sort is paid from wealth each year or after harvest for agricultural product based on a certain regulation derived from Islamic jurisprudence. ${ }^{19}$

There are at least five kinds of property that are legally responsible to be disbursed: (1) gold and silver, (2) cattle including camels, oxen, bulls, buffaloes and sheep, (3) crops of the field involving: wheat, rice, cereals, dates and grape, (4) mines and lastly (5) merchandise. The rate of each zakaable items is based on the type of wealth, for instance, $2.5 \%$ for gold, silver and trade, $10 \%$ for agricultural product which is irrigated by public irrigation or by rain or water, and $5 \%$ if the land is irrigated by the owner. Each of the zakaable items is paid whenever it reached a minimum exemption rate (nișāb) (see Table 1). ${ }^{20}$

The recipients of zaka include the poor (faqiir) the needy (masākin) the collector and distributor of zaka ('àmil), those who reconcile to Islam (mu'allaf), captives and slaves (riqāb), debtor (ghārim), in services of God (fi sabìl Allāh) and wayfarer (ibn al-sabìl). ${ }^{21}$

\footnotetext{
${ }^{19}$ S. Sabiq, Fikih Sunah 3, Bandung: PT Alma'arif, 1978, 154-157, 283-348.

20 M.D. Ali, Sistem Ekonomi Islam: Zakat dan Wakaf, Yogyakarta: UII Press, 1988.

${ }^{21}$ Inoed et. al., Anatomi Fiqh Zakat, Yogyakarta: Pustaka Pelajar, 2005.
} 
Table 1. Zaka: type of wealth, niṣāb, hawl and rate

\begin{tabular}{|c|c|c|c|c|c|}
\hline No & Type of wealth & $\begin{array}{c}\text { A minimum } \\
\text { exemption rate } \\
(\text { Nișa } b)\end{array}$ & $\begin{array}{l}\text { Duration } \\
\text { (hawl) }\end{array}$ & $\begin{array}{c}\text { Rate of } \\
\text { Zaka }\end{array}$ & Explanation \\
\hline 1 & Gold & 96 gram & 1 year & $2.5 \%$ & \\
\hline 2 & Silver & 672 gram & 1 year & $2.5 \%$ & \\
\hline 3 & Mines & $\begin{array}{l}\text { Equivalent to } 96 \\
\text { gram of gold }\end{array}$ & 1 year & $2.5 \%$ & \\
\hline 4 & $\begin{array}{l}\text { Trading, company, } \\
\text { and income }\end{array}$ & $\begin{array}{l}\text { Equivalent to } 96 \\
\text { gram of gold }\end{array}$ & 1 year & $2.5 \%$ & \\
\hline
\end{tabular}

1. Goat, Sheep

$\begin{array}{rrr}40-120 & 1 \text { year } & 1 \\ 121-200 & & 2 \\ 201-300 & & 3\end{array}$

Every 100

add of

sheep /

goat, the

rate of Zaka

is plus one

2. Cow

\begin{tabular}{|c|c|c|}
\hline 301 year & $\begin{array}{l}1 \text { of a } \\
\text { year old }\end{array}$ & $\begin{array}{l}\text { Every } 30 \\
\text { add of cow, }\end{array}$ \\
\hline 1 year & $\begin{array}{l}\text { cow } \\
\text { a two }\end{array}$ & $\begin{array}{l}\text { the rate of } \\
\text { Zaka is plus }\end{array}$ \\
\hline 1 year & $\begin{array}{l}\text { years of } \\
\text { cow }\end{array}$ & $\begin{array}{l}1 \text { of two } \\
\text { years old of }\end{array}$ \\
\hline 1 year & $\begin{array}{l}2 \text { of a } \\
\text { year old } \\
\text { cow } \\
1 \text { of a } \\
\text { year old } \\
\text { cow plus } \\
1 \text { of two } \\
\text { years of } \\
\text { cow }\end{array}$ & cow \\
\hline
\end{tabular}

3. buffalo and horse the same as 1 year the same The rule is cow as cow the same as cow's rule

6 Crops

1. Paddy / rice

$1.350 \mathrm{~kg}$ of Every $5 \%$ or gabah is gabah or 750 harvest $10 \%$ unhulled $\mathrm{kg}$ rice paddy separated from the stalks 
2. Others agriculture Equivalent to

The rule is product like $1.350 \mathrm{~kg}$ of wheat, cereals, gabah or 750 the same as fruits and etc. $\mathrm{kg}$ of rice paddy/ rice's rule

The second component is shadaqa. Shadaqa literally means righteousness coming from the root word shadaqa, "to speak the truth or to be true". This term is usually referred as the voluntary alms giving that is emerged from the willingness of the donor as befit certain arrange of condition. This differs from zaka that the amount of contribution is fixed and ruled out by Islamic law. ${ }^{22}$ The term shadaqa is mentioned several time in the Qur' an, in the chapters 2:195, 2:263, 2:264, 2:276, 9:58, 9:60, 9:79, 9:104, 58:13.23 This can play role as a charity form for needy people. In the wider context, shadaqa is not limited to money, it can be a form of smile or helping to relieve someone's feeling, thus poor people can also contribute it to others. ${ }^{24}$

The third and fourth elements are infaq and hibah. This infaq and hibah are also forms of welfare system due to the fact that both of them are charity act to help others. Infaq is voluntarily spending income giving to others whenever they receive revenue. While hibah is disbursement of wealth to assist other or social institution, religious foundation without expecting reward from the receiver. ${ }^{25}$

The fifth element is waqf which means holding a certain amount of wealth (money or means of production) as a donation, which the advantage of that wealth can be taken as charitable or religious purpose. Waqf should be given in the form of sustainable wealth: it is

22 M. W. Khan, The Concept of Charity in Islam, 2005. Retrieved January 2006, from http:/ /www.alrisala.org/intro_page_link/article_categories.html

${ }^{23}$ M.D. Ali, Sistem Ekonomi Islam: Zakat dan Wakaf, Yogyakarta: UII Press, 1988, 23.

${ }^{24}$ Inoed et. al., Anatomi Fiqh Zakat, Yogyakarta: Pustaka Pelajar, 2005, 15.

25 .M.D. Ali, Sistem Ekonomi Islam: Zakat dan Wakaf, Yogyakarta: UII Press, 1988, 24. 
usually given in the form of land or investment. Waqf is usually used for education institution and mosque. This type of welfare can not be inherited and not allowed to be given as shadaqa. ${ }^{26}$

The sixth component is qurban. Qurban (immolation) is a type of welfare system in the form meat which is directly given to the poor people. It is given once a year at the month of hajj (pilgrim). Qurban is a symbol of human sacrificing through this gift, how people feed others at least once a year. ${ }^{27}$

These all kind of systems mentioned earlier are a range of Islamic attempt to foster human wellbeing. Hence, social and human welfare are basic Islamic value. Moreover, Qur'an motivates Moslem to share the good thing and reward of God with others as a matter of compulsion. ${ }^{28}$

\section{Islamic welfare system in practice}

Committee and the work of the Islamic welfare system

As mention previously that in Islam there is a welfare system as a response to the people in need. This scheme includes zaka, shadaqa, infaq, hibah, waqf and qurban. In this section, I present the practice of such scheme in the village under study although there is no official organization who manages all components of the scheme. In this case, I refer to the common committee who responsible to collect and distribute the zaka fitra and many others practice.

${ }^{26}$ I. Suhadi, Wakaf untuk Kesejahteraan Umat, Yogyakarta: PT.Dana Bhakti Prima Yasa, 2002, 18.

${ }^{27}$ S. Sirojuddin, "Toward Welfare Pluralism: Policy and Practice of the Islamic Welfare Effort in Indonesia", unpublished Master thesis for graduate school of social work at McGill University, 2004, 14.

${ }^{28}$ A. Ahmad, "Social Welfare: A Basic Islamic Value", Journal of Hamdard Islamicus, Volume XX, Number 3 (1997). Retrieved 2005, from http://www.muslim-canada.org/articles.html 
To begin with, the common committee of the scheme operated is committee of zaka fitra (alms giving which is disbursed by each Moslem in fasting month). This board is led by a chief of RW (rukun warga/ administrative unit at the next-to-lowest level in the city), this person cooperates with the chief of $R T$ (Rukun Tetangga/neighborhood association) and the selected people from each $R T$ to be a member of the committee to collect zaka fitra from the Moslem community.

This committee consists of the chief of $R W$ and $R T$ and a selected person from each $R T$ and an apparent profile in the society. This committee is responsible to collect and distribute it to the zaka receiver. This organizer usually asks advise to the religious leader in that village when they face difficulties in accordance with the implementation such scheme. Thus, in this case religious leader play as an adviser, although they are not a member of the board.

In the management level, a chief of the $R W$ becomes the leader of the committee, the apparent profile in the society is the treasurer and a chief of RT and the selected people are the collector and distributor of the almsgiving. Eventually, there is no formal structure of the organization, but from the discussion with the committee, the structure can be described in figure 1 :

The member of the board is not formally permanent especially for the chief of $R T$ and selected people. Sometimes, the leader of $R T$ is not able to participate in the management of such activity because of their business, so they delegate their task to other people in the same area. People who are selected to be members of committee are regularly changed. This changing is based on the discussion among the committee. The number of people and $R T$ involved in this board depends on the number of $R T$ in that area. 
Figure 1

The structure of zaka fitra board

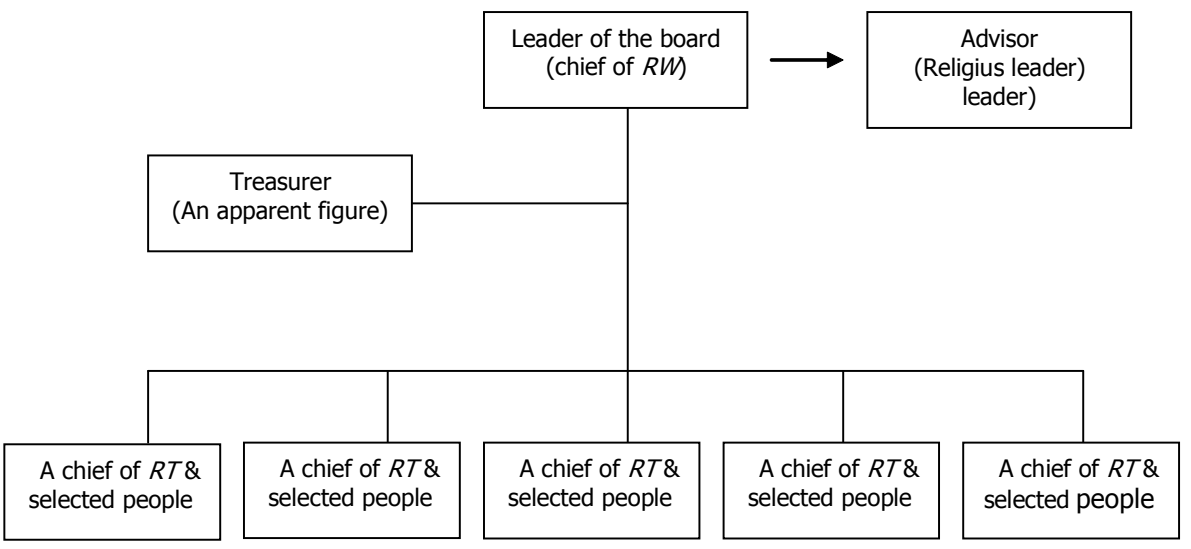

Source: interview with the zaka organizer, 2006

Each of the chief of $R T$ cooperates with the selected person in charge to collect zaka fitra from the community in its neighborhood area under their authority. They collect the levy using an active method: they usually visit muzakki's home (zaka payer). This activity is held for about ten days from the date 15 to 25 of fasting month.

After all of the alms giving are accumulated and accounted, the committee encodes the right of zaka receiver in the community. The committee prioritizes to the poor (faqiir), the needy (masākin) and the zaka administrator ('ämil) to receive these zaka. Afterwards, they counts and write it down in the list. Then, the committee discuss about how much rice will be distributed for each family receiver. After making agreement, they package the rice using a plastic bag: each plastic bag contains one kilogram of rice.

The committee distributes this levy to the mustahik two days before lebaran (day of celebration at the end of fasting month). The 
organizer argues that eventually the better day to distribute zaka fitra is a night before lebaran, however because most of the committee are busy preparing for celebrating lebaran day, the committee decides to give it two days before it. Each recipient gains four plastic of rice or equal to four kilograms averagely. Whereas, in certain cases if there is family consisting a lot of people and in deprived conditions, they will obtain more than four kilograms. Meanwhile for the 'àmil, the committee gives them approximately thirteen kilograms for the reason that these 'āmil considered as a worker. Consequently these administrators gain more portion of zaka as a reward of their work.

This alms giving is primarily proposed for family consumption and supporting them celebrate lebaran. The board of zaka fitra acknowledges that this small of zaka portion is only sufficient to supporting the beneficiaries commemorate lebaran. The organizer emphasizes that it is not enough for other aims such as economic production and improving the life of mustahik.

This organizer confesses that they have not collected zaka mäl (zaka on wealth). Usually the muzakki (zaka payer) gives it directly to the recipient. The muzakki mention that they always ask their house helper to distribute the zaka on wealth (especially agriculture product) to the recipient directly. This almsgiving is usually given to their neighborhoods that are poor and needy.

Meanwhile, other element of Islamic welfare system is organized by different committee. For instance waqf is managed by the organizer of mosque. Most people in this village donate their money to this committee for the reconstructing and maintaining of the mosque. On the other hand, for the practice of immolation the villager typically hands over the animal for immolation to the religious leader in that village. This Moslem scholar is entrusted to manage the distribution of the 
meat, he usually cooperate with the chief of $R W$ to organize it, this people then ask several people to help managing this animal of qurban. Afterwards, this informal committee slaughters the animal and then divides the meat into several portions which will be distributed to the qualified receiver. The chief of $R W$ administers the people who are considered as the right recipient, and the member of this organizer then visiting to the house of recipient to give it (for the detail of the work cycle of immolation practice sees the following figure).

Figure 2

The work cycle of immolation practice

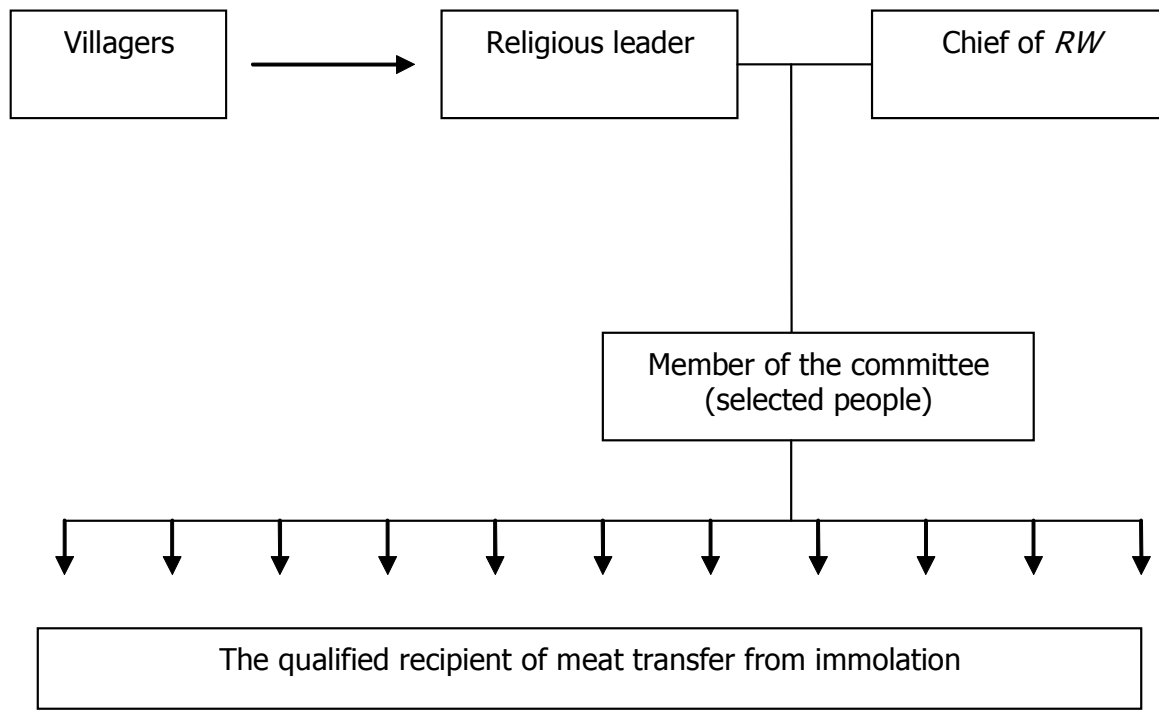

Sources: interview with the committee of immolation, 2006

The amount of meat for each recipient depends much on the amount of animal given by the villager, and the number of recipients also depends on that of animal. The more transferred animal, the more meat will be distributed to the receiver. There is no fix number of animal 
received by the committee each year: it can be four, five or six lambs.

There is no formal committee that organizes the rest of Islamic welfare system called shadaqa, infaq and hibah. Sometimes, people donate their income through the religious teaching group. This practice can be seen at the various group such as yasinan group (religious teaching group every Thursday night that usually read yasin/one of the chapters in the qur'an), barzanji group (chant recounting Muhammad's life). The amount of money in this donation is usually small: at a range from two hundred rupiah to one thousand rupiah for each person per meeting. The accumulated fund is spent for purchasing some equipment used for the group like a plaited mat, glasses and chairs. In addition, this fund is used for aiding the member of group when their family is passed away: this gift can be categorized as social support.

\section{Management of the system}

From that above description, the management of the Islamic welfare system in the village under study can be categorized as non professional activity. Each of those elements can be looked further in the table 2.

That table depicts that there are only two different informal committees dealing with zaka fitra and qurban. Both of these informal organizers are formed every year when the time of ramadhan and Idul Adha comes. These are kinds of incidental committee due to the following reasons; (1) these committees are not permanent and people who participate in that activity are regularly changing, (2) the committee only responsible in collecting and distributing the zaka fitra and meat (qurban) at fasting month and Idul Adha, therefore the committee only work at a short term. 
Table 2. Management of the system

\begin{tabular}{|c|c|c|}
\hline System & Committee & Type of committee \\
\hline Zaka fitra & $\begin{array}{l}\text { Informal committee } \\
\text { consists of: } \\
\text { - a chief of } R W \\
\text { - a selected people } \\
\text { - an apparent person }\end{array}$ & $\begin{array}{l}\text { The committee is not } \\
\text { permanent, this is formed } \\
\text { once a year every fasting } \\
\text { month }\end{array}$ \\
\hline Zaka on wealth & $\begin{array}{l}\text { No committee / muzakki } \\
\text { pay individually }\end{array}$ & - \\
\hline Waqf & The organizer of mosque & $\begin{array}{l}\text { This committee is actually the } \\
\text { manager of the mosque in } \\
\text { which they handle and } \\
\text { responsible to maintain the } \\
\text { mosque }\end{array}$ \\
\hline Qurban & $\begin{array}{l}\text { Informal committee } \\
\text { consists of: } \\
\text { - a religious leader } \\
\text { - a chief of RW } \\
\text { - a selected people }\end{array}$ & $\begin{array}{l}\text { The committee is not } \\
\text { permanent, this is formed } \\
\text { once a year every Idul Adha }\end{array}$ \\
\hline $\begin{array}{l}\text { Shadaqa, infaq, } \\
\text { hibah }\end{array}$ & $\begin{array}{l}\text { No committee / } \\
\text { People usually donate } \\
\text { their money through } \\
\text { religious teaching group }\end{array}$ & - \\
\hline
\end{tabular}

The member of the committees are people in that area without any specific criteria, the leader of the committee mentions that the 'àmil are persons from each neighborhood area, thus they are representation of such places, and usually a chief of RT is directly to be member of 'āmil; in certain cases they can delegate other person on condition that they are not able to participate because of their busyness. This is a fact that there is no consideration related to the capability and professionalism.

Both of those welfare systems manage conventionally in which the accumulated rice and meat directly given to the recipients. There is no written report to be made by the committee of qurban, while the organizer of the zaka fitra has written a report about the accumulated 
rice. The report on zaka fitra is not kept in a good manner, the committee said that the document have lost so that the development of zaka fitra from time to time can not be evaluated. Indeed, there is no program evaluation connected with those activities.

Waqf is managed by the organizer of mosque, so that the management of this Islamic welfare element is embedded with the management of mosque. This organizer has written a document of the accumulated money and the circulation of fund. There is also a periodic report to the community, the organizer has always held an open meeting with the villagers in order to report and evaluate the activity of mosque and management of waqf. Besides, the committee wrote a list of donators on the white board placed in the hall of mosque; this is one of the methods for reporting the accumulated funds and for transparency.

The member of the waqf's committee is the same as the member of mosque's organizer. This condition has weakness that these people have double tasks; in certain cases it will create ineffectiveness for instance there will be overlapping duty between mosque and waqf. Ideally waqf is managed separately by independent committee so that people in charge in that business can concern on the program or services funded by waqf.

On the other hand, there is no organizer dealing with zaka on wealth, shadaqa, infaq, and hibah. Zaka on wealth is given individually and not managed by a specific committee. While the rest of welfare elements are integrated in a variety of religious teaching group, in this case people donate their money through these meeting. These practices have many weaknesses as follows: (1) People who distribute zaka māl individually have not made a mapping data about the beneficiaries, this may cause double benefit got by certain people, while another people 
do not receive advantage; (2) this almsgiving is intended only for immediate consumption; (3) Not all muzakki understand about the real condition of beneficiaries, this may lead to giving levy to the wrong receivers; (4) This tithe can not support people's economy for a long time period.

Meanwhile, shadaqa, infaq and hibah are handled by religious teaching group. Actually, the main purpose of this group is not collecting charitable fund, this is a religious group which focuses on a religious activity. Hence, the management of those welfare schemes is integrated with that activity, it is a kind of secondary act. Ideally, as the potential components of the welfare system, shadaqa, infaq and hibah are managed by a formal institution so that it can contribute more to the wider communities.

\section{Fundraising strategies}

There are different methods in collecting fund used by the committee of Islamic welfare system. The fundraising strategy is one of the important components to achieve the goals of such scheme. The committees of those welfare systems employ different approaches, for example the organizer of the zaka fitra utilizes active way, they visiting the muzakki's home, while the organizer of waqf uses active and passive ways and the committee of qurban only apply the passive approach. For the detail description can be seen in the table 3 .

Those strategies have positive and negative sides. The active approach employed by committee of zaka fitra has good effects as follows: (1) The committee can ensure that the villagers disbursed such religious duty; (2) The rice can be collected from all villagers; (3) There is a large amount of rice can be gathered. In contrast, visiting each muzzaki's home takes a long time and this activity needs many people to be involved. 
Table 3. Fundraising strategies

\begin{tabular}{|c|c|c|}
\hline System & Type & Methods \\
\hline Zaka fitra & Active & Visiting muzaki's home \\
\hline Waqf & Active and passive & $\begin{array}{l}\text { asking the villager to donate } \\
\text { certain amount of money } \\
\text { - waiting people donate their } \\
\text { money voluntarily }\end{array}$ \\
\hline Qurban & Passive & $\begin{array}{l}\text { Waiting people donate the animal } \\
\text { for immolation willingly }\end{array}$ \\
\hline
\end{tabular}

Waqf as a source of welfare fund is collecting by asking villagers to donate their money and waiting people give resources voluntarily. To implement the first method, the committee held meeting with the community. In that gathering they discuss about the need of mosque's reconstruction and maintenance, and this project requires a lot of money. Thus the committee encourages people to participate in supporting it, the committee then asks and makes an agreement with the people in which these people will provide certain amount of money. While the second way, the committee only waits people giving their money charitably.

Actually, the committee of qurban plays as facilitator to distribute meat to the right recipients. They wait people asking them to manage and transfer the meat. If there is no one who hands over the animal to the religious leader, there will no committee of immolation. Therefore, the existence of the immolation's board depends on the animals that are taken over by such giver.

Other systems including zaka on wealth, shadaqa, infaq and hibah are usually disbursed individually since there is no formal institution handling these schemes. Therefore, there is no fundraising strategy that can be assessed. 


\section{The aims of the scheme}

The purposes of the practice of Islamic welfare system are mainly to provide immediate consumption, for instance, the committee of zaka fitra and qurban mentions that due to the small amount of rice and meat, they distribute it directly to the beneficiaries for consumptive intention. Similarly, people paid zaka on wealth state that they give it to the poor and needy just for helping them feeding their family. Moreover, waqf is intended for renovation and preservation of the mosque. Shadaqa, infaq and hibah that are usually collected through religious teaching group are proposed for buying some equipment for the group, and in certain cases it is for aiding the member of the group when their family passed away. This following table summarized the goal of the system;

Table 4. The goals of the system

\begin{tabular}{ll}
\hline System & Purposes \\
\hline Zaka fitra & $\begin{array}{l}\text { To support people celebrate lebaran day. } \\
\text { For people's consumption }\end{array}$ \\
Waqf on wealth & For people consumption \\
Qurban & $\begin{array}{l}\text { For reconstruction and maintenance of the } \\
\text { mosque }\end{array}$ \\
Shadaqa, infaq, hibah & For people's consumption \\
& $\begin{array}{l}\text { To purchase equipment for the group. } \\
\text { To aid the member of the group when their } \\
\text { family passed away }\end{array}$ \\
\hline
\end{tabular}

All of the purposes indicate that there are no programs for long term period which may be needed by the right receivers. Almost all of the accumulated fund or meat in this system is distributed in time. 
Thus, there are no more funds that can be used for supporting other services like providing capital for poor people including peasants' community.

The table 5 and 6 reveals that such system does not deal with the economic production, this is solely a kind of redistribution from the have to the have not. Indeed waqf does not touch on the wellbeing of people, but rather it only provides a place for praying to God. The practice of waqf tends to follow the conventional model in which waqf is not for empowering people in need. The way people transfer their money for waqf can be considered as a contemporary model because in cash waqf is hardly ever applied by most people; mostly they give land or other static properties for waqf

People accessibility to the Islamic welfare system

Selected people as the member of the society who are in the vulnerable condition should have access to the Islamic welfare system. The accessibility to such scheme is a way to look how this system benefits to one of the right receivers. In this section, I examine the people's ease of access to this system by looking at peasant participation in the management level, and what advantages are gained by the people in terms of promoting wellbeing. This people's accessibility to the system can be looked at the table below:

Table 5. People participation in the committee of welfare system

\begin{tabular}{|c|c|c|c|c|c|c|c|c|c|}
\hline $\begin{array}{l}\text { Participation in the } \\
\text { committee }\end{array}$ & 1 & 2 & 3 & 4 & 5 & 6 & 7 & 8 & 9 \\
\hline Zaka fitra & - & - & - & - & - & - & - & $\sqrt{ }$ & - \\
\hline Qurban & - & - & - & $\sqrt{ }$ & - & - & - & $\sqrt{ }$ & $\sqrt{ }$ \\
\hline Waqf & - & - & - & - & - & - & - & $\sqrt{ }$ & - \\
\hline
\end{tabular}


Table 6. Benefit that gained from the welfare system (as the receivers)

\begin{tabular}{llllllllll}
\hline $\begin{array}{l}\text { Advantage / as } \\
\text { receiver of the } \\
\text { welfare system }\end{array}$ & 1 & 2 & 3 & 4 & 5 & 6 & 7 & 8 & 9 \\
\hline Zaka fitra & $\sqrt{ }$ & $\sqrt{ }$ & $\sqrt{ }$ & $\sqrt{ }$ & $\sqrt{ }$ & $\sqrt{ }$ & - & - & $\sqrt{ }$ \\
$\begin{array}{l}\text { Qurban } \\
\text { Zaka on wealth }\end{array}$ & $\sqrt{ }$ & $\sqrt{ }$ & $\sqrt{ }$ & $\sqrt{ }$ & $\sqrt{ }$ & $\sqrt{ }$ & $\sqrt{ }$ & $\sqrt{ }$ & $\sqrt{ }$ \\
\hline
\end{tabular}

Note: number $1,2,3$ - 9 refer to the informan

Not all informan have participated in the management level of this welfare system. It is conventionally practiced that the member of the organizer of those welfare scheme are male people, as a consequent women in that community is indirectly excluded from it. However, they say that some of them usually receive zaka fitra in the fasting month, almsgiving on wealth (agriculture product especially unhulled paddy separated from the stalk/gabah) when the time of harvest from the muzzaki, and meat in the month of hajj (Idul Adha). These people mentions that they obtain zaka fitra at about four kilograms of rice, they use it for celebrating lebaran. They cook it and then serve it to the guest who visiting them. While, the gabah got from the zaka on wealth and meat from the immolation is used for their family consumption.

\section{Discussion and conclusion}

The poor people can be classified as the right recipient of Islamic welfare system (specifically zaka) together with other beneficiaries namely captives and slaves, debtor, those who reconcile to Islam, in services of God, and wayfarer. ${ }^{29}$ Nevertheless, In this village there is no formal institution who organize all element of such scheme (zaka,

${ }^{29}$ Inoed et. al., Anatomi Fiqh Zakat, Yogyakarta: Pustaka Pelajar, 2005. 
waqf, shadaqa, infaq, hibah and qurban). The Islamic welfare system operated in this village is managed conventionally. The zaka fitra is organized by informal committee that is lead by a chief of $R W$. In contrast, there is no organizer of zaka on wealth, the zaka payer usually distribute it directly to the recipient. Similarly, there is no formal institution who manages another form of the scheme like shadaqa, infaq and hibah. Meanwhile waqf is organized by the manager of mosque because the accumulated of the donation is typically used for mosque maintenance. Moreover, immolation is also managed by informal committee.

As the social welfare institution, this system ideally offers program, benefits and services that help people meets those social, economic, educational and health needs. ${ }^{30}$ However, there is no specific programs for the poor people offered by the committee of the Islamic welfare scheme, nevertheless this scheme (zaka fitra) at least have contribute to support people celebrate lebaran. ${ }^{31}$ And hence, it is as a form of redistribution of wealth from the have to the have not. There are many reasons why this scheme does not respond directly to the problem of poor people: (1) the limited amount of almsgiving that is accumulated in the committee, as a result the portion of levy which is given to the mustahik is very small; (2) the committee of the welfare argues that poor and needy people is the right person who will get the benefit, so that poor people is included in that beneficiaries along with others.

On the other hand, zaka on wealth which is supposed to be the main source of welfare provision have not played much on countering people's problems. Selected people mention that they receive zaka on agriculture when the time of harvest comes, but the amount of farm

\footnotetext{
${ }^{30}$ C.H. Zastrow, The Practice of Social Work, USA: Brooks/Cole Publishing Company, 1999. ${ }^{31}$ S. Sabiq, Fikih Sunah 3, Bandung: PT Alma'arif, 1978.
} 
product is usually small which is only for immediate family consumption. So that it can not support them to gain their wellbeing. Indeed, there is no institution that manages this scheme. The muzakki distribute it individually, this is just a kind of incidental redistribution of the sources from the have to the have not. ${ }^{32}$ Similarly, meat from the immolation committee is only intended for people's consumption. This form of scheme can not advantage much on the welfare of the recipients including poor people. These facts indicate that generally the Islamic welfare system in this village has not played much as strategy to promote a good life and welfare for people. Hence, it is still far from the ideal concept of social welfare provision for the society.

Meanwhile, poor people as others in that community have the same access to such system. They receive the benefit of the welfare although it can not play much to enhance their wellbeing. They have also opportunity to be member of the committee, thus they can participate in the management level of such committee.

After having that above discussion, I propose several recommendations to the board of that welfare system; the first, it is really needed a kind of formal institution which manages all of the system in the village level. This organization should be run professionally, which can play as provider of services for the community including social asset building, economic production as well as cash transfer. These three of programs have different propose and target group. The social asset building is intended to enhance people access to the social services like health care and education. This service can be funded by zaka, shadaqa, infaq and hibah. This service can be a scholarship for the poor students and social fund for aiding the cost of medication specifically for

32 P. Spicker, Social Policy Themes and Approaches, England: Prentice Hall, 1995. 
poor people. The economic production is a program that provide capital for small entrepreneur, this fund should also allocate for enhancing capability of the community in this profession by providing program called entrepreneurship assistance. While cash transfer is proposed for aiding people in need for immediate term or consumptive aim.

\section{Bibliography}

Ahmad, A, "Social Welfare: A Basic Islamic Value", Journal of Hamdard Islamicus, Volume XX, Number 3 (1997), retrieved 2005, from http://www.muslim-canada.org/articles.html

Ali, M. D. Sistem Ekonomi Islam: Zakat dan Wakaf. Yogyakarta: UII Press, 1988.

Azmi, S.H., "Traditional Islamic Social Welfare: its Meaning, History and Contemporary Relevance", The Islamic Quarterly, XXXV (1991).

Azizi, Q. Membangun Fondasi Ekonomi Umat; Meneropong Prospek Perkembangan Ekonomi Islam. Yogyakarta: Pustaka Pelajar, 2004. Babbie, E. The Practice of Social Research (eight edition). USA: Wadsworth Publishing Company, 1998.

Burke, P. Sejarah dan Teori Sosial. Jakarta: Yayasan Obor Indonesia, 2003.

CBS (Central Statistic Bureau) (2001, 2003, 2004, 2005). Potensi Daerah Jawa Tengah. Retrieved December 2005, from http:// www.bps.go.id

CBS. Kecamatan Bandongan Dalam Angka Tahun 2003. Magelang: BPS Kabupaten Magelang, 2003.

CBS. Kabupaten Magelang Dalam Angka Tahun 2004. Magelang: BPS Kabupaten Magelang, 2004. 
Chapra, U., "The Islamic Welfare State and its Role in the Economy", in K. Ahmad (ed.), Studies in Islamic Economics. Leicester, U.K: The Islamic Foundation, 1980: 143-169.

Departmern of Religious Affair. Al-Qur'an dan Terjemahannya. Jakarta: Proyek pengadaan kitab suci Al-Qur'an Dept. Agama RI, 1982.

Dobelstein, A. Social Welfare: Policy and Analysis (3 ${ }^{\text {rd }}$ Edition). Pacific Grove, CA: Thomson Brooks/Cole, 2003.

Dolgoff, R \& Feldstein, D. Understanding Social Welfare. New York: Harper \& Row Publishers, 1980.

Ellor, J.W \& Min, D \& Tribault, J.M. Understanding Religious and Spiritual Aspect of Human Service Practice. Columbia, South Carolina: University of South Carolina Press, 1999.

Faridi, "Zaka and Fiscal Policy", in K. Ahmad (ed), Studies in Islamic Economics. Leicester, U.K: The Islamic Foundation, 1980: 119129.

Hamidullah, M. Zakat, State Expenditure, Budgeting. 1997. Retrieved 2005, from http://www.muslim-canada.org/articles.html

Inoed et. al. Anatomi Fiqh Zakat. Yogyakarta: Pustaka Pelajar, 2005. Jones, C., "Poverty and Social Exclusion", in Davies, M. (ed.). Companion to Social Work. Great Britain: Blackwell Publishing, 1997.

Kahf, M., "The Principle of Socioeconomic Justice in the Contemporary Fiqh of Zaka", Iqtisad Journal of Islamic Economics, Volume 1, Number 1 (1999): 24-44.

Khan, M.W. The Concept of Charity in Islam. 2005. Retrieved January 2006, from http://www.alrisala.org/intro_page_link/ article_categories.html 
Leonard, P. Postmodern Welfare; Reconstructing an Emancipatory Project. London: SAGE Publication, 1997.

Link, R.J \& Bibus, A., "Global Aproaches to Learning Social Welfare Policy", in Link, R.J \& Ramanathan, C.S (Eds.). All Our Futures: Principles \& Resources for Social Work Practice in Global Era. Belmont, CA: Wadsworth/Thomson Learning, 2004.

Lobban, C. F. Islamic Society in Practice. USA: University Press Florida, 1994.

Marlow, C. Research Methods for Generalist Social Work. Toronto: Brooks/Cole, 2001.

Midgley, J. Social Welfare in Global Context. London: Sage Publication, 1997.

Midgley, J. Social Development: the Development Perspective in Social Welfare. London: SAGE Publication, 2004.

Moon, S.M., "Take off or Self-Sufficiency? Ideologies of Development in Indonesia, 1957-1961", Journal of Technology and Culture, Volume 39, Number 2 (April 1998).

Muhtada, D., "Zaka and Peasant Empowerment: Case Study on Zaka Organizations in Yogyakarta", unpublished Master thesis for graduate school of social work at State Islamic University Sunan Kalijaga, 2005.

Qardhawi, Y. Teologi Kemiskinan: Doktrin Dasar dan Solusi Islam atas Problem Kemiskinan. Yogyakarta: Mitra Pustaka, 2002.

Rubin, A \& Babbie, E. Research Method for Social Work (4 ${ }^{\text {th }}$ Edition). Pacific Grove, CA: Wadsworth, 2000.

Rahmat, J. Islam Alternatif: Ceramah Ceramah di Kampus. Bandung: Mizan, 1986. 
Rofiq, A. Fiqh Kontekstual: dari Normatif ke Pemaknaan Sosial. Yogyakarta: Pustaka Pelajar, 2004.

Sabiq, S. Fikih Sunah 3. Bandung: PT Alma'arif, 1978.

Sherraden, M. Assets and the Poor: A New American Welfare Policy. New York: M.E.Sharpe Inc, 1991.

Sirojuddin, S., "Toward Welfare Pluralism: Policy and Practice of the Islamic Welfare Effort in Indonesia", unpublished Master thesis for graduate school of social work at McGill University, 2004.

Shiddieqy, H.A. Pedoman Zakat. Semarang: Pustaka Rizki Putra, 2005. Spicker, P. Social Policy Themes and Approaches, England: Prentice Hall, 1995.

Suhadi, I. Wakaf untuk Kesejahteraan Umat. Yogyakarta: PT.Dana Bhakti Prima Yasa, 2002.

The World Bank. Reaching the Rural Poor; A Renewed Strategy for Rural Development. Washington DC: The International Bank for Reconstruction and Development, 2003.

Yegidis, B.L. \& Weinbach, R,W. Research Method for Social Work (2nd Edition). Needham, MA: Allyn and Bacon, 1996.

Zastrow, C.H. Introduction to Social Work and Social Welfare. USA: Thompson Brooks/Cole, 2004.

Zastrow, C.H. The Practice of Social Work. USA: Brooks/Cole Publishing Company, 1999. 